\title{
Laparoscopic surgery facilitates administration of adjuvant chemotherapy in locally advanced colon cancer: propensity score analyses
}

This article was published in the following Dove Press journal: Cancer Management and Research

\author{
Karin ATGM Wasmann' \\ Charlotte EL Klaver' \\ Jarmila DW van der Bilt ${ }^{1,2}$ \\ Susan van Dieren ${ }^{3}$ \\ Iris D Nagtegaal ${ }^{4}$ \\ Cornelis JA Punt ${ }^{5}$ \\ Bert van Ramshorst ${ }^{6}$ \\ Albert M Wolthuis ${ }^{2}$ \\ Johannes HW de Wilt ${ }^{7}$ \\ André D'Hoore ${ }^{2}$ \\ Hjalmar C van Santvoort ${ }^{6}$ \\ Pieter J Tanis' \\ 'Department of Surgery, Amsterdam \\ University Medical Centre, University of \\ Amsterdam, AZ I 105, Amsterdam, The \\ Netherlands; ${ }^{2}$ Department of Abdominal \\ Surgery, University Hospital Leuven, \\ Leuven 3000, Belgium; ${ }^{3}$ Clinical Research \\ Unit, Amsterdam University Medical \\ Centre, University of Amsterdam, AZ \\ I 105, Amsterdam, The Netherlands; \\ ${ }^{4}$ Department of Pathology, Radboud \\ University Medical Centre, GA 6525, \\ Nijmegen, The Netherlands; \\ ${ }^{5}$ Department of Medical Oncology, \\ Amsterdam University Medical Centre, \\ University of Amsterdam, AZ I I05, \\ Amsterdam, The Netherlands; \\ ${ }^{6}$ Department of Surgery, St. Antonius \\ Hospital, CM 3435, Nieuwegein, The \\ Netherlands; ' ${ }^{7}$ Department of Surgery, \\ Radboud University Medical Centre, GA \\ 6525, Nijmegen, The Netherlands
}

Correspondence: Karin ATGM Wasmann Department of Surgery, Amsterdam University Medical Centre, University of Amsterdam, Room G4I40, Meibergdreef

9, Amsterdam II05, AZ, The

Netherlands

Tel +3I $20566297 \mid$

Fax +31 20566699 I

Email k.a.wasmann@amc.nl
Purpose: The aim of this study was to evaluate the impact of a laparoscopic approach on long-term oncological outcomes in curative intent surgery for pT4 colon cancer, in both overall and stratified subgroups with distinct clinical entities.

Patients and methods: Patients with a pT4N0-2M0 colon cancer from four centers between 2000 and 2014 were included. Laparoscopic and open approaches were compared according to the intention-to-treat principle. Propensity scores were used to adjust for baseline differences between the groups in three manners: i) as a linear predictor in a Cox regression model, ii) to create a 1:1 matched cohort, and iii) to stratify patients into four groups with an increasing chance of receiving laparoscopy.

Results: In total, 424 patients were included. After 1:1 matching, a laparoscopic approach correlated with higher rates of radical resection, lower morbidity, and a higher percentage of patients receiving adjuvant chemotherapy. This translated into better 5-year disease-free survival (52\% vs $40 \%$, HR $0.70 ; 95 \%$ CI $0.50-0.96)$ and 5 -year overall survival (68\% vs $57 \%$, HR 0.66; 95\% CI 0.43-0.99). These results were confirmed in the other two propensity score analyses. In the multivariable models, adjuvant chemotherapy remained independently associated with better survival, whereas surgical approach lost significance.

Conclusions: In locally advanced colon cancer, an intentional laparoscopic approach in experienced hands seems to decrease morbidity and to increase the proportion of patients receiving adjuvant chemotherapy. Receiving adjuvant chemotherapy was independently associated with improved survival.

Keywords: T4 colon cancer, laparoscopy, lower GI

\section{Synopsis}

In this multicenter propensity score analyses of 424 pT4N0-2M0 colon cancer patients who underwent curative intent surgery, laparoscopic surgery compared to open was associated with reduced postoperative morbidity and a higher percentage of patients receiving adjuvant chemotherapy, which translated into improved survival.

\section{Introduction}

Resection of locally advanced (T4) colon cancer stage is still regarded as a relative contraindication for laparoscopic surgery, because radicality of the resection (R0) might be jeopardized, thereby impacting the long-term oncological outcome. ${ }^{1}$

Laparoscopic surgery for colon cancer has become widely accepted and implemented in routine practice for localized disease (pT1-3). Both favorable short-term 
and long-term benefits have been demonstrated, ${ }^{2-5}$ including less postoperative complications, shorter hospital stay, lower risks of adhesion-related small bowel obstruction, and incisional hernia compared to open surgery. ${ }^{6}$ In the multicenter randomized COLOR trial, ${ }^{7}$ the noninferiority of laparoscopic surgery for pT1-4 colon cancer in terms of oncological outcomes (3-year disease-free survival, DFS) was suggested. However, clinically suspected tumor invasion of adjacent structures (cT4b stage) and emergency surgery were exclusion criteria. Due to a conversion rate of about $50 \%$ for the remaining T4 tumors in the COLOR data, the authors presumed the open approach to be most appropriate for $\mathrm{T} 4$ colon cancer.

Experience with laparoscopic surgery for $\mathrm{T} 4$ tumors increases, and the concerns on achieving radicality of resection may be outdated. Accumulating series of laparoscopic resections of $\mathrm{T} 4$ colon cancer are published, ${ }^{8-18}$ and two recent meta-analyses ${ }^{19,20}$ show comparable rates of R0 resections and long-term oncological outcomes after laparoscopic versus open surgery. However, only a limited body of evidence is available and is restricted to retrospective series with substantial allocation bias. ${ }^{19,20}$ Also, emergency cases and multivisceral resections (MVR, pT4b) were often excluded in the previous series.

The aim of this multicenter cohort study was to evaluate long-term oncological outcomes after curative intent laparoscopic surgery for pT4 colon cancer and compare it to open surgery using propensity score analyses in order to correct for allocation bias.

\section{Methods}

\section{Patients and databases}

In this cohort study, four prospectively maintained databases of the University Hospital Leuven, the Dutch (teaching) St. Antonius Hospital, and two Dutch university medical centers (Radboud UMC and Amsterdam UMC) were combined (centers 1-4). The database of center 1 contained all consecutive patients who underwent resection of colon cancer between January 2004 and July 2013. The databases of centers 2 and 3 included all pT4 colorectal cancer patients undergoing surgery between January 2000 and December 2013, and between January 2000 and December 2007, respectively. The database of center 4 included all pT4 colon cancer patients who underwent surgery between January 2004 and December 2014. Patients undergoing a curative intent pT4N0-2M0 primary colon cancer resection were included. Patients with a macroscopic incomplete (R2) resection or with an inadequate pathological or surgical report were excluded. Adjuvant chemotherapy was administered according to the national protocols: indicated in high-risk stage II and stage III, consisting of 5-flourouracil or capecitabine and preferably combined with oxaliplatin (FOLFOX or CAPOX) since 2005, for a total duration of 6 months. Follow-up was performed according to the national protocol and data were collected until April 2018. ${ }^{21,22}$ This study was waived from the review of the medical ethics boards, since the prospective data collection did not interfere with the psychological integrity of the patients. The study is reported in accordance with the STROBE checklist.

\section{Variables and outcomes}

The pT4 stage was subdivided into pT4a and pT4b according to TNM7: ${ }^{23}$ pT4a refers to tumors perforating the visceral peritoneum and $\mathrm{pT} 4 \mathrm{~b}$ refers to tumors directly invading other organs or structures. MVR could be either limited or extensive: limited additional resection included the abdominal wall, the omentum, or the ovaries, and extensive resection was defined as resections including the pancreas, spleen, kidney, liver, stomach, bladder, ureters, uterus, or additional bowel segments.

The primary outcome measures were DFS and overall survival (OS). Secondary outcomes were radicality of resection, classified as R0 (radical resection) and R1 (microscopically irradical resection) resections, administration of adjuvant chemotherapy, and postoperative complications $(<30$ days or in hospital). Postoperative complications were registered if the Clavien-Dindo ${ }^{24}$ (CD) score was 2 or higher. Postoperative morbidity was defined as CD $2-4$, and postoperative mortality as CD5.

\section{Statistical analyses}

The laparoscopic converted procedures were included in the laparoscopic group according to "intention-to-treat principle". For each patient, a propensity score was calculated, displaying the probability of receiving laparoscopic surgery based on a multivariable logistic regression model including (potential) confounding baseline variables. Potential confounders were variables only affecting outcome measures, and true confounders were variables affecting both choice for surgical approach and outcome measures. ${ }^{25}$ Confounders included age, emergency setting, tumor location (right/left), MVR (none/limited/extended), $\mathrm{N}$-stage, and histopathology. The choice for variables 
included in the model was based on identified (potential) confounders in the previous series. ${ }^{8,9,11,19}$ Due to multicollinearity between MVR and T4 subcategory (T4a/T4b), the latter was not included in the propensity score calculation.

The propensity score was used in three different manners to adjust for group differences, all with distinct advantages and disadvantages. ${ }^{25,26}$ Firstly, the propensity score was used as a linear predictor in Cox regression analyses (referred to as "Regression adjusted"), from which an estimated effect was derived. In this way, the entire cohort could be included in the analysis. In order to minimize baseline differences before statistical comparison, the propensity score was used for 1:1 matching with a caliper width of 0.02 and using matching without replacement (referred to as "Matched cohort"). Besides comparison of the two matched cohorts, the excluded cohort of open surgery after matching was analyzed and compared to the included matched open cohort. Thirdly, the propensity score was used to subdivide patients into four strata based on quartiles of the propensity scores, creating an equal distribution of confounding variables within the four strata (referred to as 'Strata 1-4'). For each stratum, baseline and outcome variables were compared between laparoscopic and open subgroups. This method uses the entire cohort and creates clinically relevant subgroups from a surgical perspective. In addition, sensitivity analyses were performed for MVR and emergency surgery.

Differences in baseline characteristics between subgroups were assessed using a chi-square test for categorical variables or a Fisher's exact test in case of low counts $(<5)$. For normally distributed continuous variables, mean and SD were reported. The survival analyses were performed using Kaplan-Meier and Cox regression analyses. A $p$-value of $<0.05$ was considered statistically significant in the multivariable analyses. For statistical analyses, PASW Statistics, version 24 (SPSS inc., Chicago, IL) was used.

\section{Results \\ Patients}

A total of 424 patients that underwent macroscopic complete (R0/R1) resection of primary pT4N0-2M0 colon cancer in one of the four participating centers were included (Figure S1). Mean age was 69 years (SD 12) and 51\% of patients were male. Laparoscopic surgery was performed in 131 patients (31\%), of which 33 procedures were converted (25\%). A MVR was performed in 171 patients $(40 \%)$ and emergency surgery in 60 patients (14\%). Median follow-up was 48 months (IQR 22-60). Baseline characteristics are displayed in Table 1. The following baseline characteristics were significantly different for the laparoscopic and open groups, respectively: emergency setting ( $5 \%$ vs $18 \%$, $p<0.001$ ), MVR ( $31 \%$ vs $45 \%, p=0.014$ ), and T4 subcategory (T4a: $81 \%$ vs $66 \%, p=0.002$ ).

Numbers of performed resections between the centers were $164(39 \%)$ in center $1,113(27 \%)$ in center 2, 90 $(21 \%)$ in center 3 , and $57(13 \%)$ in center 4 with significantly different laparoscopy rates $(42 \%, 24 \%, 3 \%$, and $56 \%$, respectively; $p<0.001)$ and conversion rates $(38 \%$, $11 \%, 67 \%$, and $6 \%$, respectively; $p=0.001$ ). No differences in case mix were found between centers 2,3 , and 4 , while center 1 showed higher rates of elective surgery and lower rates of MVRs and pT4b tumors (Table S1).

\section{Unadjusted analysis of outcome measures}

The R0 resection rate was higher in the laparoscopic group as compared to the open group ( $99 \%$ vs $93 \%, p=0.010$ ). The postoperative morbidity rate was lower after laparoscopic surgery $(27 \%$ vs $46 \%, p<0.001)$ and postoperative mortality rates were comparable ( $2 \%$ vs $3 \%, p=0.357)$. Adjuvant chemotherapy was more often administered after laparoscopic surgery $(60 \%$ vs $44 \%, p=0.004)$. Laparoscopy was significantly associated with better 5 -year DFS (52\% vs 38\%, $p=0.008)$ and 5-year OS (68\% vs $57 \%, p=0.023$ ) (Tables 2 and S2, Figures 1 and 2).

\section{Regression adjusted analysis}

The distributions of propensity scores are displayed in Figure 1. After adjusting for the propensity score in regression models, R0 resection rate (OR 0.16 ; $95 \%$ CI $0.02-$ 1.25 ) as well as postoperative mortality (OR $0.73 ; 95 \% \mathrm{CI}$ 0.14-3.68) were comparable between the two approaches, while postoperative morbidity was lower (OR 0.48 ; 95\% CI $0.30-0.77)$ and the rate of administration of adjuvant chemotherapy higher (OR 1.94; 95\% CI 1.25-3.03) after laparoscopic surgery. Five-year DFS was significantly better in the laparoscopic group (HR $0.70 ; 95 \%$ CI $0.52-$ 0.94 ), without significant benefit for 5-year OS (HR 0.73; 95\%CI 0.50-1.06) (Figure 2).

\section{Propensity matched analysis}

In Figure 1, the distributions of propensity scores are displayed for the propensity matched cohort. Within the propensity matched cohort $(n=262)$, no baseline differences were found between the laparoscopic and open groups (Table 3), apart from the center. The excluded open group 
Table I Baseline characteristics of the entire cohort for the laparoscopic and the open group

\begin{tabular}{|c|c|c|c|c|c|c|}
\hline & & \multicolumn{2}{|c|}{ Lap $(n=|3|)$} & \multicolumn{2}{|c|}{ Open $(n=293)$} & \multirow[b]{2}{*}{$p$-Value } \\
\hline & & $\mathbf{n}$ & $\%$ & $\mathbf{n}$ & $\%$ & \\
\hline \multirow[t]{2}{*}{ Gender } & Male & 68 & $52 \%$ & 148 & $51 \%$ & \multirow[t]{2}{*}{0.790} \\
\hline & Female & 63 & $48 \%$ & 145 & $49 \%$ & \\
\hline \multirow[t]{4}{*}{ Age } & $\leq 60$ & 29 & $22 \%$ & 73 & $25 \%$ & \multirow[t]{4}{*}{0.783} \\
\hline & $61-70$ & 37 & $28 \%$ & 75 & $26 \%$ & \\
\hline & $7 I-80$ & 41 & $31 \%$ & 99 & $34 \%$ & \\
\hline & $\geq 81$ & 24 & $18 \%$ & 46 & $16 \%$ & \\
\hline \multirow[t]{4}{*}{ Hospital } & Center I & 69 & $53 \%$ & 95 & $32 \%$ & \multirow[t]{4}{*}{$<0.001$} \\
\hline & Center 2 & 27 & $21 \%$ & 86 & $29 \%$ & \\
\hline & Center 3 & 3 & $2 \%$ & 87 & $30 \%$ & \\
\hline & Center 4 & 32 & $24 \%$ & 25 & $9 \%$ & \\
\hline \multirow[t]{2}{*}{ Location tumour } & Right & 56 & $43 \%$ & 126 & $43 \%$ & \multirow[t]{2}{*}{0.961} \\
\hline & Left/transverse & 75 & $57 \%$ & 167 & $57 \%$ & \\
\hline \multirow[t]{5}{*}{ Surgical procedure } & (Extended) right hemicolectomy & 60 & $46 \%$ & 127 & $43 \%$ & \multirow[t]{5}{*}{0.140} \\
\hline & Transverse resection & 0 & $0 \%$ & 8 & $3 \%$ & \\
\hline & (Extended) left hemicolectomy & 13 & $10 \%$ & 42 & $14 \%$ & \\
\hline & (Low) anterior/sigmoid resection & 51 & $39 \%$ & 94 & $32 \%$ & \\
\hline & Subtotal/panprocto-colectomy & 7 & $5 \%$ & 22 & $8 \%$ & \\
\hline \multirow[t]{2}{*}{ Setting } & Elective & 125 & $95 \%$ & 239 & $82 \%$ & \multirow[t]{2}{*}{$<0.001$} \\
\hline & Emergency & 6 & $5 \%$ & 54 & $18 \%$ & \\
\hline \multirow[t]{2}{*}{ Neoadjuvant therapy } & Yes & 5 & $4 \%$ & 14 & $5 \%$ & \multirow[t]{2}{*}{0.681} \\
\hline & No & 124 & $96 \%$ & 279 & $95 \%$ & \\
\hline \multirow[t]{3}{*}{ MVR } & No & 91 & $69 \%$ & 162 & $55 \%$ & \multirow[t]{3}{*}{0.014} \\
\hline & Yes, limited & 19 & $15 \%$ & 50 & $17 \%$ & \\
\hline & Yes, extended & 21 & $16 \%$ & 81 & $28 \%$ & \\
\hline Conversion & & 33 & $25 \%$ & NA & & NA \\
\hline \multirow[t]{2}{*}{ pT-stage } & T4a & 106 & $81 \%$ & 193 & $66 \%$ & \multirow[t]{2}{*}{0.002} \\
\hline & $\mathrm{T} 4 \mathrm{~b}$ & 25 & $19 \%$ & 100 & $34 \%$ & \\
\hline \multirow[t]{3}{*}{ pN-stage } & No & 64 & $49 \%$ & 139 & $47 \%$ & \multirow[t]{3}{*}{0.963} \\
\hline & $\mathrm{NI}$ & 38 & $29 \%$ & 88 & $30 \%$ & \\
\hline & N2 & 29 & $22 \%$ & 66 & $23 \%$ & \\
\hline \multirow[t]{3}{*}{ Histology } & Adenocarcinoma (well diff) & 94 & $72 \%$ & 197 & $67 \%$ & \multirow[t]{3}{*}{0.333} \\
\hline & Adenocarcinoma (poorly/undiff) & 15 & $11 \%$ & 50 & $17 \%$ & \\
\hline & Mucinous/signet ring cells & 22 & $17 \%$ & 46 & $16 \%$ & \\
\hline
\end{tabular}

Abbreviations: Lap, laparoscopic approach; MVR, multivisceral resection; NA, not applicable; Open, open approach; pT/N, pathological T/N-stage; Undiff, undifferentiated; Well diff, well differentiated.

$(n=162)$ after 1:1 matching contained more emergency cases as compared to the included open group (29\% vs $5 \%, p<0.001)$ as well as more MVRs (57\% vs $29 \%$, $p<0.001)$ and more pT4b tumors (44\% vs $21 \%, p<0.001)$.

Laparoscopic surgery as compared to open surgery in the $1: 1$ matched cohort revealed higher $\mathrm{R} 0$ resection rates (99\% vs 95\%, $p=0.030)$, lower postoperative morbidity $(27 \%$ vs $72 \%, p<0.001)$, a trend toward lower postoperative mortality ( $2 \%$ vs $8 \%, p=0.051$ ), and comparable rates of administration of adjuvant chemotherapy $(60 \%$ vs $54 \%, p=0.301)$. Five-year DFS was significantly better in the laparoscopic group (52\% vs 
$40 \%, p=0.038)$, as well as 5-year OS (68\% vs $57 \%$, $p=0.044$ ) (Figure 1). Survival rates of patients that were excluded from the open group after propensity matching were comparable with the included open group (5-year DFS 37\%, $p=0.664$ and 5-year OS 57\%, $p=0.914)$.

\section{Propensity score-based strata}

After dividing the entire cohort into four strata based on quartiles of the propensity scores, with stratum 1 containing the lowest propensity for laparoscopic surgery, the R0 resection rates were higher in all strata (although nonsignificant), postoperative morbidity, mainly CD2 complications, was lower in stratum 4 ( $22 \%$ vs $43 \%, p=0.031)$, adjuvant chemotherapy higher in strata 2 and 3 and survival outcomes favorable in all strata (although nonsignificant) after laparoscopic surgery vs open (Table 2 and Figure 2). Baseline characteristics of the four strata are provided in Table S3-S6. Stratum 1 contains all emergency cases as well as the highest percentage of extended MVRs (50\%). Stratum 2 also includes a high percentage of MVRs (limited MVR 30\%, extended MVR 47\%), whereas the MVR rates of strata 3 and 4 are $16 \%$ and $0 \%$, respectively.

\section{Sensitivity analyses}

After sensitivity analyses, no subgroup of patients (eg emergency setting) could be identified in which oncological outcomes of laparoscopic surgery were inferior to outcomes after open surgery (Table 2 and Figure 2). In the "no-MVR" subgroup, DFS and OS were significantly better, and in the extended MVR and elective cases, more adjuvant chemotherapy was administered after laparoscopic surgery as compared to open surgery. For elective cases also, a significant better DFS was seen after laparoscopy.

\section{Adjuvant chemotherapy}

Post hoc analyses showed that after adjusting for adjuvant chemotherapy in the Cox regression models, the beneficial effect of laparoscopic surgery on DFS and OS did not remain significant, neither in the unadjusted nor in the regression adjusted and the 1:1 matched cohort. In every multivariable model, adjuvant chemotherapy was significantly associated with improved DFS (HR 0.46; 95\% CI 0.35-0.61, HR 0.54; 95\% CI 0.41-0.71 and HR 0.37; 95\% CI 0.24-0.56, respectively) and OS (HR 0.49; 95\% CI 0.33-0.72, HR 0.44; 95\% CI $0.31-0.62$ and HR $0.31 ; 95 \%$ CI $0.19-0.51$, respectively), both in stage II and stage III subgroups (data not shown).

\section{Discussion}

In this multicenter series of $424 \mathrm{pT} 4 \mathrm{~N} 0-2 \mathrm{M} 0$ colon cancer patients who underwent curative intent surgery, laparoscopic surgery was associated with reduced postoperative morbidity and a higher percentage of patients receiving adjuvant chemotherapy. The multivariable models revealed an independent association of adjuvant chemotherapy with improved survival, but not surgical approach. This suggests that laparoscopic surgery facilitates the administration of adjuvant chemotherapy by improving postoperative recovery and reducing complication rates, with ultimate gain in survival.

Table 2 Short-term oncological outcomes after laparoscopic and open surgery

\begin{tabular}{|l|l|l|l|l|l|l|l|}
\hline \multirow{2}{*}{} & \multirow{2}{*}{ Lap/Open } & \multicolumn{2}{l|}{ Radicality } & \multicolumn{2}{l|}{ Adj. chemo } \\
\cline { 3 - 7 } & & Lap & Open & $p$-Value & Lap & Open & $p$-Value \\
\hline Unadjusted & $131 / 293$ & $130(99 \%)$ & $271(93 \%)$ & $0.010 *$ & $75(60 \%)$ & $127(44 \%)$ & 0.004 \\
\hline Propensity score adjusted models & & & & & \\
Matched cohort & $131 / 131$ & $130(99 \%)$ & $123(95 \%)$ & $0.030 *$ & $75(60 \%)$ & $68(54 \%)$ & 0.301 \\
Stratum I & $15 / 90$ & $15(100 \%)$ & $78(89 \%)$ & 0.191 & $9(53 \%)$ & $41(47 \%)$ & 0.233 \\
Stratum 2 & $32 / 75$ & $31(97 \%)$ & $68(92 \%)$ & 0.317 & $20(69 \%)$ & $28(37 \%)$ & 0.004 \\
Stratum 3 & $39 / 69$ & $39(100 \%)$ & $66(96 \%)$ & 0.257 & $26(70 \%)$ & $33(45 \%)$ & 0.027 \\
Stratum 4 & $45 / 59$ & $45(100 \%)$ & $59(100 \%)$ & & $20(44 \%)$ & $25(46 \%)$ & 0.920 \\
\hline Sensitivity analyses & & & & & & \\
No MVR & $91 / 162$ & $90(99 \%)$ & $157(97 \%)$ & 0.298 & $53(60 \%)$ & $74(48 \%)$ & 0.061 \\
Limited MVR & $19 / 50$ & $19(100 \%)$ & $45(90 \%)$ & 0.152 & $7(44 \%)$ & $17(34 \%)$ & 0.338 \\
Extended MVR & $21 / 81$ & $21(100 \%)$ & $69(89 \%)$ & 0.103 & $15(71 \%)$ & $36(44 \%)$ & 0.028 \\
Elective & $125 / 239$ & $124(99 \%)$ & $223(95 \%)$ & 0.027 & $72(60 \%)$ & $107(46 \%)$ & 0.010 \\
Emergency & $6 / 54$ & $6(100 \%)$ & $48(89 \%)$ & 0.516 & $3(60 \%)$ & $20(39 \%)$ & 0.330 \\
\hline
\end{tabular}

Abbreviations: Adj. chemo, adjuvant chemotherapy; Lap, laparoscopic approach; MVR, multivisceral resection; Open, open approach; Unadjusted, the unadjusted (entire) cohort. 

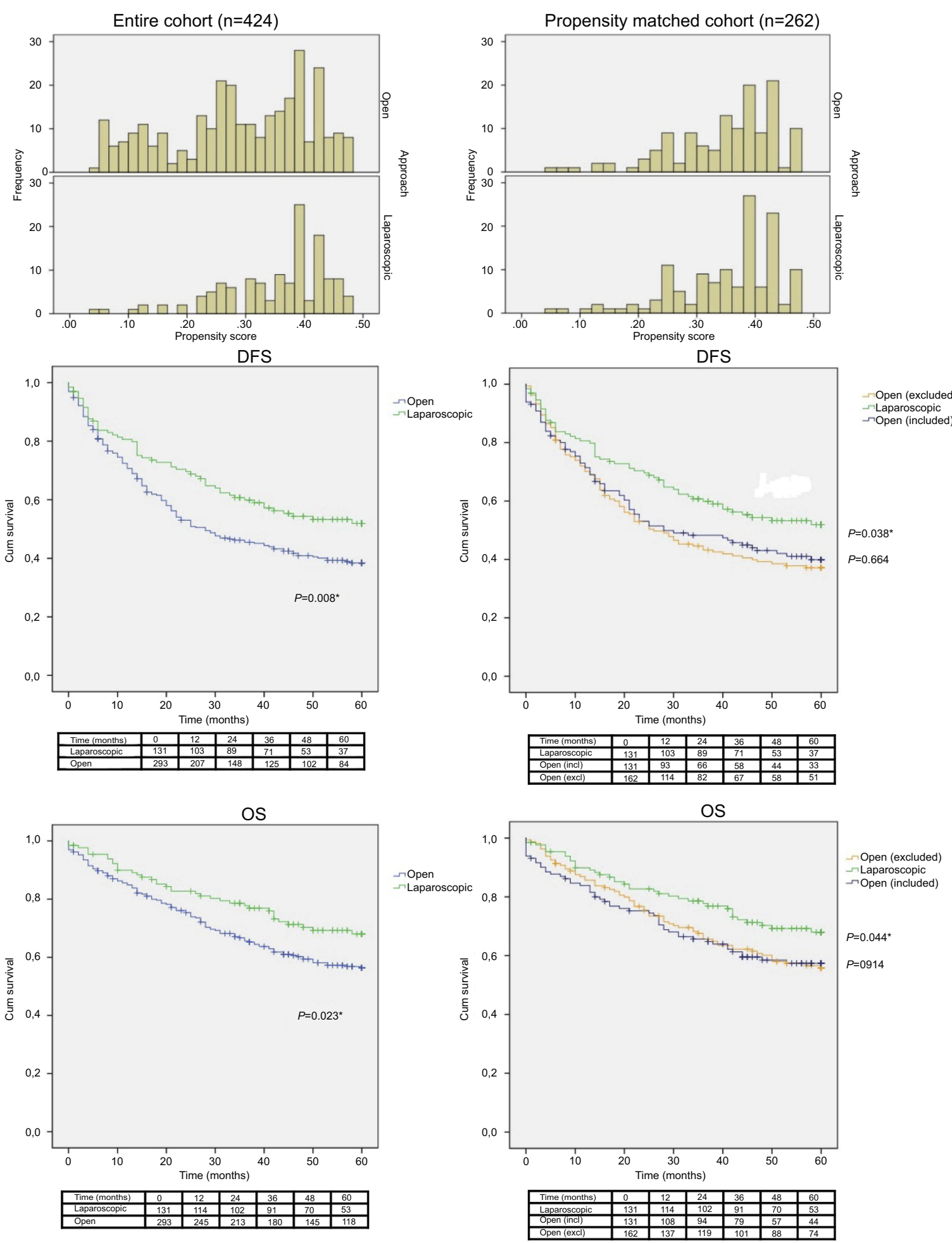

Figure I Propensity score distribution, disease-free survival (DFS), and overall survival (OS) in the entire cohort and the propensity matched cohort.

Abbreviations: Laparoscopic, laparoscopic approach; Open, open approach; DFS, disease-free survival; OS, overall survival; cum, cumulative; open (excl), open approach, excluded from the matched cohort; open (incl), open approach, included from the matched cohort.

A recently published Chinese expert series ${ }^{27}$ similarly observed higher survival rates after laparoscopic surgery (5-year DFS $57 \%$ vs $40 \%, p=0.053,5$-year OS $61 \%$ vs
$47 \%, p=0.060)$. The increased likelihood of receiving adjuvant chemotherapy due to better recovery from minimally invasive surgery has also recently been observed. 


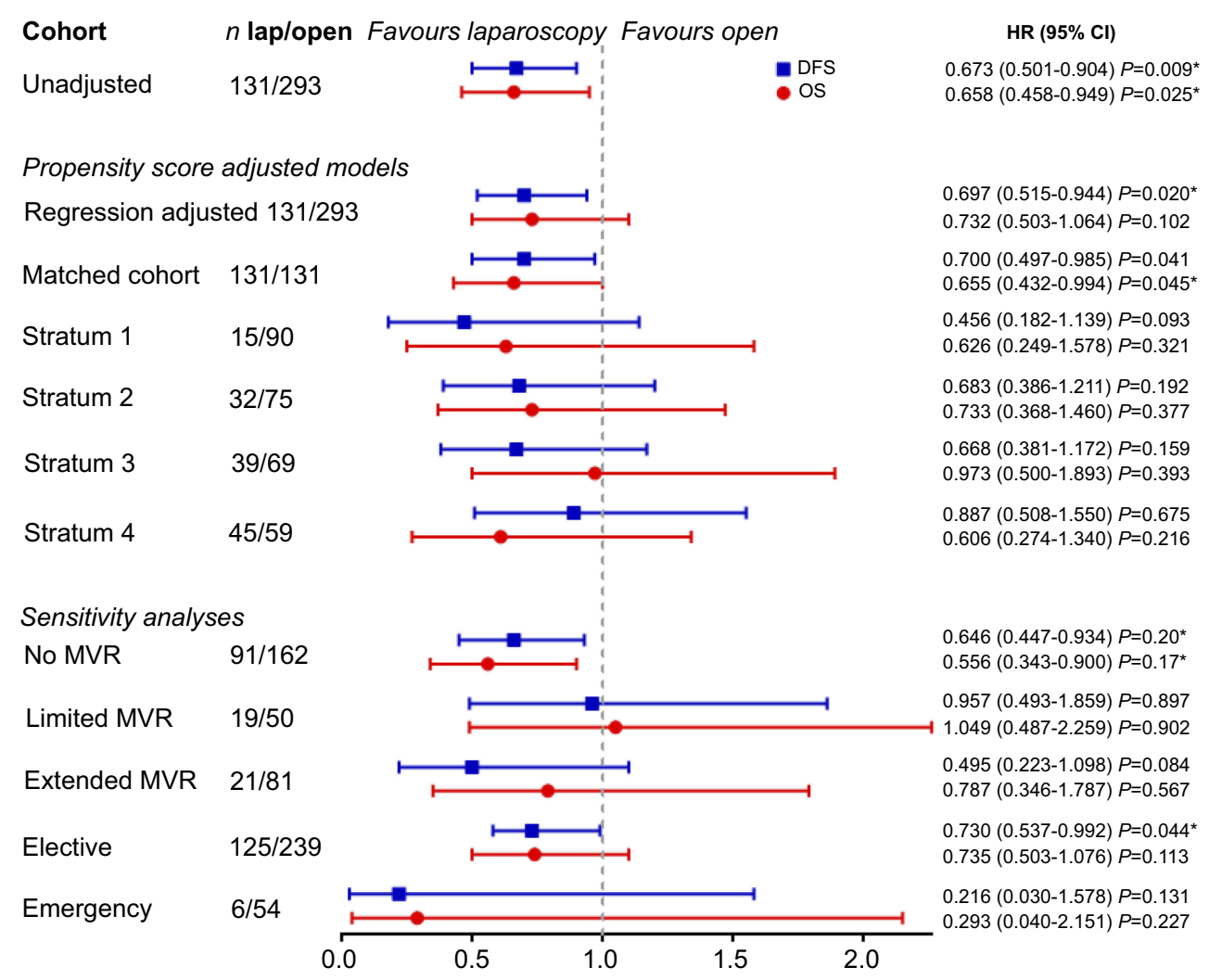

Figure 2 Disease-free (DFS) and overall survival (OS).

Abbreviations: Lap, laparoscopic approach; MVR, multiviscersal resection; Open, open approach; unadjusted, the unadjusted (entire) cohort; DFS, disease-free survival; $\mathrm{OS}$, overall survival; $\mathrm{HR}$, hazard ratio; $\mathrm{Cl}$, confidence interval.

Lee et al reported higher rates and less delay to the initiation of adjuvant chemotherapy after laparoscopic surgery for stage III colon cancer in a propensity matched cohort of 66,266 patients, ultimately resulting in improved survival. But this is a new insight that has not previously been described in the literature. ${ }^{28}$ In randomized controlled trials, such as the COLOR trial, ${ }^{7}$ comparable rates of adjuvant chemotherapy and survival after laparoscopic and open surgery are likely related to strict inclusion of relatively fit patients with small tumors, being operated upon in the elective setting. Therefore, randomized controlled trials have restricted external validity. We hypothesize that more extended application of laparoscopy by experienced surgeons in routine practice is now going to shed a different light on the impact of minimally invasive surgery. The most pronounced differences in administration of adjuvant chemotherapy between laparoscopy and open surgery were found in the extended MVR subgroup ( $71 \%$ vs $44 \%$ ) and in the emergency setting (60\% vs 39\%), suggesting that minimizing surgical trauma is only becoming clinically relevant in such high-risk patients. Two series including substantial numbers of T4b cases also reported higher rates of adjuvant chemotherapy after laparoscopic as compared to open surgery $(63 \%$ vs $37 \%$, $p=0.047$ and $71 \%$ vs $57 \%, p=0.513) .{ }^{13,16}$

The main reason why T4 colon cancer has been considered a contraindication for laparoscopic surgery was the concern about achieving complete resection with negative margins, especially in the case of local ingrowth (pT4b). In this multicenter series, a 100\% R0 resection rate in 40 patients requiring MVR was found. Four studies assessed outcomes after laparoscopic resection of $\mathrm{pT} 4 \mathrm{~b}$ colon cancer in relatively small cohorts of 15-23 patients. ${ }^{9,11,13,20,29} \mathrm{R} 0$ resection rates were $83 \%, 93 \%, 96 \%$, and $100 \%$, respectively. For experienced surgeons in open MVR who also completed the learning curve for laparoscopic colon surgery, the laparoscopic approach might eventually facilitate dissection in locally advanced cases. This is related to the magnified view at high resolution with a 30-degree camera that enables optimal visualization from different angles, which, for example, might improve dissection from the retroperitoneum below a bulky tumor as compared to median laparotomy. It is often considered that tactile feedback is missing in laparoscopy, but there is still an indirect sense of firmness of tissues. Furthermore, high-quality MVR has become more and more dependent on thorough preoperative 
Table 3 Baseline characteristics of the matched cohort for the laparoscopic and the open group

\begin{tabular}{|c|c|c|c|c|c|c|c|c|}
\hline & & \multicolumn{2}{|c|}{ Lap $(n=|3|)$} & \multicolumn{2}{|c|}{ Open $(n=|3|)$} & \multirow[t]{2}{*}{$p$-Value } & \multicolumn{2}{|c|}{ Open excl $(n=\mid 62)$} \\
\hline & & $\mathbf{n}$ & $\%$ & $\mathbf{n}$ & $\%$ & & $\mathbf{n}$ & $\%$ \\
\hline \multirow[t]{2}{*}{ Gender } & Male & 68 & $52 \%$ & 68 & $52 \%$ & 1.000 & 80 & $49 \%$ \\
\hline & Female & 63 & $48 \%$ & 63 & $48 \%$ & & 82 & $51 \%$ \\
\hline \multirow[t]{4}{*}{ Age } & $\leq 60$ & 29 & $22 \%$ & 31 & $24 \%$ & 0.924 & 42 & $26 \%$ \\
\hline & $61-70$ & 37 & $28 \%$ & 37 & $28 \%$ & & 38 & $24 \%$ \\
\hline & $7 \mid-80$ & 41 & $31 \%$ & 43 & $33 \%$ & & 56 & $35 \%$ \\
\hline & $\geq 81$ & 24 & $18 \%$ & 20 & $15 \%$ & & 26 & $16 \%$ \\
\hline \multirow[t]{4}{*}{ Hospital } & Center I & 69 & $53 \%$ & 47 & $36 \%$ & $<0.001$ & 48 & $30 \%$ \\
\hline & Center 2 & 27 & $21 \%$ & 28 & $21 \%$ & & 58 & $36 \%$ \\
\hline & Center 3 & 3 & $2 \%$ & 45 & $34 \%$ & & 42 & $26 \%$ \\
\hline & Center 4 & 32 & $24 \%$ & 11 & $8 \%$ & & 14 & $9 \%$ \\
\hline \multirow[t]{2}{*}{ Location tumour } & Right & 56 & $43 \%$ & 51 & $39 \%$ & 0.530 & 75 & $46 \%$ \\
\hline & Left/transverse & 75 & $57 \%$ & 80 & $61 \%$ & & 87 & $54 \%$ \\
\hline \multirow[t]{6}{*}{ Surgical procedure } & (Extended) right hemicolectomy & 60 & $46 \%$ & 51 & $39 \%$ & 0.071 & 76 & $47 \%$ \\
\hline & Transverse resection & 0 & $0 \%$ & 5 & $4 \%$ & & 3 & $2 \%$ \\
\hline & (Extended) left & & & & & & & \\
\hline & Hemicolectomy & 13 & $10 \%$ & 20 & $15 \%$ & & 22 & $13 \%$ \\
\hline & (Low) anterior/sigmoid resection & 51 & $39 \%$ & 44 & $34 \%$ & & 50 & $31 \%$ \\
\hline & Subtotal/panprocto-colectomy & 7 & $5 \%$ & 11 & $8 \%$ & & 11 & $7 \%$ \\
\hline \multirow[t]{2}{*}{ Setting } & Elective & 125 & $95 \%$ & 124 & $95 \%$ & 0.776 & 115 & $71 \%$ \\
\hline & Emergency & 6 & $5 \%$ & 7 & $5 \%$ & & 47 & $29 \%$ \\
\hline \multirow[t]{2}{*}{ Neoadjuvant therapy } & Yes & 5 & $4 \%$ & 8 & $7 \%$ & 0.409 & 6 & $4 \%$ \\
\hline & No & 124 & $96 \%$ & 123 & $93 \%$ & & 156 & $96 \%$ \\
\hline \multirow[t]{3}{*}{ MVR } & No & 91 & $70 \%$ & 93 & $71 \%$ & 0.747 & 69 & $43 \%$ \\
\hline & Yes, limited & 19 & $15 \%$ & 15 & $12 \%$ & & 35 & $22 \%$ \\
\hline & Yes, extended & 21 & $16 \%$ & 23 & $17 \%$ & & 58 & $36 \%$ \\
\hline Conversion & & 33 & $25 \%$ & NA & & NA & NA & \\
\hline \multirow[t]{2}{*}{ pT-stage } & $\mathrm{T} 4 \mathrm{a}$ & 106 & $81 \%$ & 103 & $79 \%$ & 0.645 & 90 & $56 \%$ \\
\hline & T4b & 25 & $19 \%$ & 28 & $21 \%$ & & 72 & $44 \%$ \\
\hline \multirow[t]{3}{*}{ pN-stage } & No & 64 & $49 \%$ & 63 & $48 \%$ & 0.830 & 76 & $47 \%$ \\
\hline & $\mathrm{NI}$ & 38 & $29 \%$ & 42 & $32 \%$ & & 46 & $28 \%$ \\
\hline & N2 & 29 & $22 \%$ & 26 & $20 \%$ & & 40 & $25 \%$ \\
\hline \multirow[t]{3}{*}{ Histology } & Adenocarcinoma (well diff) & 94 & $72 \%$ & 96 & $73 \%$ & 0.872 & 101 & $62 \%$ \\
\hline & Adenocarcinoma (poorly/undiff) & 15 & $11 \%$ & 16 & $12 \%$ & & 34 & $21 \%$ \\
\hline & Mucinous/signet ring cells & 22 & $17 \%$ & 19 & $15 \%$ & & 27 & $17 \%$ \\
\hline
\end{tabular}

Abbreviations: Lap, laparoscopic approach; MVR, multivisceral resection; NA, not applicable; Open, open approach; Open excl, open approach, excluded from the matched cohort; $\mathrm{PT} / \mathrm{N}$, pathological T/N-stage; Undiff, undifferentiated; Well diff, well differentiated.

anatomical planning of the surgical planes of dissection. Performing minimally invasive surgery increases the skills in intraoperative recognition of (disturbed) anatomy. The proven better hemostatic dissection with less blood loss also favors the laparoscopic approach. Even if a larger incision is needed for extraction of a bulky pT4b tumor, laparoscopy might be the preferred approach by reducing surgical stress response and because of flexibility in the site of extraction to reduce the risk of incisional hernia (eg Pfannenstiel).

Occurrence of severe postoperative complications is an important factor that precludes the use of adjuvant chemotherapy. ${ }^{30}$ Postoperative infection requiring re-intervention (CD3) or ICU admission (CD4) were highest in the extended MVR and emergency subgroups undergoing open 
surgery ( $31 \%$ and $28 \%$, respectively). This likely reduced the possibilities of administration of adjuvant chemotherapy in these subgroups. Moreover, it has been increasingly described in the literature that postoperative complications have an independent adverse effect on oncological outcomes, possibly related to upregulation of inflammatory cytokines that enhance tumor progression. ${ }^{31-33}$

Previously published series comparing laparoscopic and open surgery for pT4 colon cancer often address the issue of allocation bias with more advanced cases in the open subgroup contained. In this analysis, we have attempted to overcome this bias by using propensity scores and by not excluding MVR and emergency cases. Propensity scores control for baseline differences inherent to observational studies. ${ }^{25}$ However, the present analysis might still be subject to allocation bias. We have only roughly subdivided MVRs in "limited" and "extended", while still the more complex extended MVRs could be assigned to the open subgroup. Furthermore, the number of emergency cases were limited. We did not correct for effects such as tumor size, presence of intraabdominal infections, presence of adhesions, body mass index, and comorbidity. Consequently, hidden confounding by allocation to laparoscopic or open surgery (selecting patients) could have occurred for which propensity score analyses do not correct. Nonetheless, we have implemented the propensity scores using different manners and results were comparable amongst all analyses. This represents the best achievable evidence, as new RCTs comparing surgical approach in T4 colon cancer are unlikely to be conducted. Previous RCTs comparing surgical techniques have struggled with differences in completion of learning curves amongst the participating surgeons. ${ }^{34-36}$ Rouanet et al proposed to compare a series of expert centers that apply different surgical techniques as an alternative for RCTs, in this way overcoming the problems of learning curves and allocation bias. ${ }^{37}$ Our study approaches this methodology to some extent, by including two centers (1 and 4) with relatively high laparoscopic surgery rates ( $42 \%$ and $56 \%$ ), and one participating hospital applying open surgery in $97 \%$ of cases, with comparable case mixes. However, the conversion rate of $38 \%$ in center 1 suggests that the learning curve has not been fully completed during the study period.

Another limitation of the study is the retrospective data collection with difficulties in the uniformity of defining variables and potential underestimation of the postoperative complication rate. However, postoperative complication rates among the four hospitals were comparable or even higher than previously published. ${ }^{38}$

\section{Conclusion}

In conclusion, this multicenter cohort study showed that laparoscopic surgery for pT4 colon cancer was associated with a lower risk of postoperative morbidity and a higher chance of receiving adjuvant chemotherapy. Receiving adjuvant chemotherapy was independently associated with better survival, which indicates an indirect impact of surgical approach on oncological outcome. However, these results might not be generalizable due to the level of experience in advanced laparoscopic surgery. Centralization of care for pT4 colon cancer should be aimed for, and future series of expert centers performing laparoscopic surgery for $\mathrm{T} 4$ colon cancer, especially in the more technically challenging cases, should further confirm our hypothesis.

\section{Acknowledgments}

No funding was received for this study. The current study was not preregistered in an independent or institutional registry. The authors are willing to share data, methods, and other study materials. Requests can be sent to the corresponding author.

\section{Disclosure}

The authors report no conflicts of interest in this work.

\section{References}

1. Amri R, Bordeianou LG, Sylla P, Berger DL. Association of radial margin positivity with colon cancer. JAMA Surg. 2015;150:890-898. doi:10.1001/jamasurg.2015.1525

2. Nelson H, Sargent DWH. A comparison of laparoscopically assisted and open colectomy for colon cancer. $N$ Engl J Med. 2004;350:20502059. doi:10.1056/NEJMoa032651

3. Guillou PJ, Quirke P, Thorpe H, et al. Short-term endpoints of conventional versus laparoscopic-assisted surgery in patients with colorectal cancer (MRC CLASICC trial): multicentre, randomised controlled trial. Lancet. 2005;365(9472):1718-1726. doi:10.1016/ S0140-6736(05)66545-2

4. Lacy AM, García-Valdecasas JC, Delgado S, et al. Laparoscopyassisted colectomy versus open colectomy for treatment of non-metastatic colon cancer: a randomised trial. Lancet. 2002;359(9325):22242229. doi:10.1016/S0140-6736(02)07571-2

5. Veldkamp R, Kuhry E, Hop WC, et al. Laparoscopic surgery versus open surgery for colon cancer: short-term outcomes of a randomised trial. Lancet Oncol. 2005;6(7):477-484. doi:10.1016/S1470-2045(05) 70221-7

6. Pecorelli N, Greco M, Amodeo S, Braga M. Small bowel obstruction and incisional hernia after laparoscopic and open colorectal surgery: a meta-analysis of comparative trials. Surg Endosc. 2017;31(1):85-99. 
7. Colon Cancer Laparoscopic or Open Resection Study Group, Buunen M, Veldkamp R, et al. Survival after laparoscopic surgery versus open surgery for colon cancer: long-term outcome of a randomised clinical trial. Lancet Oncol. 2009;10(1):44-52. doi:10.1016/S1470-2045(09)70234-7

8. Elnahas A, Sunil S, Jackson TD, Okrainec A, Quereshy FA. Laparoscopic versus open surgery for $\mathrm{T} 4$ colon cancer: evaluation of margin status. Surg Endosc. 2016;30(4):1491-1496.

9. Vignali A, Ghirardelli L, Di Palo S, Orsenigo E, Staudacher C. Laparoscopic treatment of advanced colonic cancer: a case-matched control with open surgery. Color Dis. 2013;15(8):944-948. doi:10.1111/ codi. 12170

10. Allaix ME, Degiuli M, Arezzo A, Arolfo S, Morino M. Does conversion affect short-term and oncologic outcomes after laparoscopy for colorectal cancer? Surg Endosc. 2013;27(12):4596-4607. doi:10.1007/s00464-013-3094-1

11. de'Angelis N, Vitali GC, Brunetti F, et al. Laparoscopic vs. open surgery for T4 colon cancer: A propensity score analysis. Int $J$ Colorectal Dis. 2016;31(11):1785-1797.

12. Kim IY, Kim BR, Kim YW. The short-term and oncologic outcomes of laparoscopic versus open surgery for T4 colon cancer. Surg Endosc. 2016;30(4):1508-1518.

13. Nagasue Y, Akiyoshi T, Ueno M, et al. Laparoscopic versus open multivisceral resection for primary colorectal cancer: comparison of perioperative outcomes. J Gastrointest Surg. 2013;17(7):1299-1305. doi:10.1007/s11605-012-2091-3

14. Park JS, Huh JW, Park YA, et al. Clinically suspected T4 colorectal cancer may be resected using a laparoscopic approach. BMC Cancer. 2016;16(1):714. doi:10.1186/s12885-016-2753-8

15. Shukla PJ, Trencheva K, Merchant C, et al. Laparoscopic resection of T4 colon cancers: is it feasible? Dis Colon Rectum. 2015;58(1):2531. doi:10.1097/DCR.0000000000000220

16. Takahashi R, Hasegawa S, Hirai K, et al. Safety and feasibility of laparoscopic multivisceral resection for surgical $\mathrm{T} 4 \mathrm{~b}$ colon cancers: retrospective analyses. Asian J Endosc Surg. 2017;10(2):154-161. doi:10.1111/ases.12355

17. Chan DKH, Tan -K-K. Laparoscopic surgery should be considered in T4 colon cancer. Int J Colorectal Dis. 2017;32(4):517-520.

18. Kang J, Baik SH, Lee KY, Sohn S-K. Outcomes of laparoscopic surgery in pathologic T4 colon cancers compared to those of open surgery. Int J Colorectal Dis. 2017;32(4):531-539.

19. Feinberg AE, Chesney TR, Acuna SA, Sammour T, Quereshy FA. Oncologic outcomes following laparoscopic versus open resection of pT4 colon cancer. Dis Colon Rectum. 2017;60(1):116-125. doi:10.1097/DCR.0000000000000641

20. Klaver CEL, Kappen TM, Borstlap WAA, Bemelman WA, Tanis PJ. Laparoscopic surgery for T4 colon cancer: a systematic review and meta-analysis. Surg Endosc Other Interv Tech. 2017;31(12):4902-4912.

21. Peeters M, Leroy M, Robays J, et al. Colon cancer: diagnosis, treatment and follow-up. Good Clinical Practice (GCP) Brussels: Belgian Health Care Knowledge Centre (KCE). 2014. Available from: https:// kce.fgov.be/sites/default/files/atoms/files/KCE_218_Colon_cancer. pdf. Accessed July 23, 2019.

22. Integraal Kankercentrum Nederland. Colorectaalcarcinoom Landelijke richtlijn, Versie: 3.0 [Colorectal carcinoma Rural guideline, version: 3.0]; 2014. Available from: https://www.nhg.org/sites/default/files/con tent/nhg_org/uploads/colorectaalcarcinoom.pdf. Accessed July 17, 2019.

23. Sobin L, Gospodarowicz M, Wittekind C. TNM Classification of Malignant Tumours. 7th ed. Chichester: Wiley Blackwell; John Wiley \& Sons Ltd; 2009.
24. Dindo D, Demartines N, Clavien P-A. Classification of surgical complications: a new proposal with evaluation in a cohort of 6336 patients and results of a survey. Ann Surg. 2004;240(2):205-213. doi:10.1097/01.sla.0000133083.54934.ae

25. Austin PC. An introduction to propensity score methods for reducing the effects of confounding in observational studies. Multivariate Behav Res. 2011;46(3):399-424. doi:10.1080/00273 171.2011 .568786

26. Shida D, Ochiai H, Tsukamoto S, Kanemitsu Y. Long-term outcomes of laparoscopic versus open D3 dissection for stage II/III colon cancer: results of propensity score analyses. Eur J Surg Oncol. 2018;44:1025-1030. doi:10.1016/j.ejso.2018.03.022

27. Yang Z-F, Wu D-Q, Wang -J-J, Lv Z-J, Li Y. Short- and long-term outcomes following laparoscopic vs open surgery for pathological T4 colorectal cancer: 10 years of experience in a single center. World $J$ Gastroenterol. 2018;24(1):76-86. doi:10.3748/wjg.v24.i1.76

28. Lee L, Wong-Chong N, Kelly JJ, et al. Minimally invasive surgery for stage III colon adenocarcinoma is associated with less delay to initiation of adjuvant systemic therapy and improved survival. Surg Endosc. 2018;33(2):460-470

29. Vallribera Valls F, Filippo Landi B, Eloy Espín Basany B, et al. Laparoscopy-assisted versus open colectomy for treatment of colon cancer in the elderly: morbidity and mortality outcomes in 545 patients. Surg Endosc. 2014;28:3373-3378. doi:10.1007/s00464-014-3597-4

30. Shayeb ME, Scarfe A, Yasui Y, Winget M. Reasons physicians do not recommend and patients refuse adjuvant chemotherapy for stage III colon cancer: a population based chart review. BMC Res Notes. 2012;5:269. doi:10.1186/1756-0500-5-269

31. Oosterling SJ, van der Bij GJ, Bögels M, et al. Anti-beta1 integrin antibody reduces surgery-induced adhesion of colon carcinoma cells to traumatized peritoneal surfaces. Ann Surg. 2008;247(1):85-94. doi:10.1097/SLA.0b013e3181588583

32. Artinyan A, Orcutt ST, Anaya DA, et al. Infectious postoperative complications decrease long-term survival in patients undergoing curative surgery for colorectal cancer. Ann Surg. 2015;261(3):497505. doi: $10.1097 /$ SLA. 0000000000000756

33. Nespoli A, Gianotti L, Totis M, et al. Correlation between postoperative infections and long-term survival after colorectal resection for cancer. Tumori. 2004;90(5):485-490. doi:10.1177/03008916040 9000508

34. Songun I, Putter H, Kranenbarg EM-K, Sasako M, van de Velde CJH. Surgical treatment of gastric cancer: 15-year follow-up results of the randomised nationwide Dutch D1D2 trial. Lancet Oncol. 2010;11 (5):439-449. doi:10.1016/S1470-2045(10)70070-X

35. Draaisma WA, Buskens E, Bais JE, et al. Randomized clinical trial and follow-up study of cost-effectiveness of laparoscopic versus conventional Nissen fundoplication. Br J Surg. 2006;93(6):690-697. doi:10.1002/bjs.5284

36. McCulloch P, Taylor I, Sasako M, Lovett B, Griffin D. Randomised trials in surgery: problems and possible solutions. BMJ. 2002;324 (7351):1448-1451.

37. Rouanet P, Gourgou S, Gogenur I, et al. Rectal Surgery Evaluation Trial: protocol for a parallel cohort trial of outcomes using surgical techniques for total mesorectal excision with low anterior resection in high-risk rectal cancer patients. Colorectal Dis. 2019;21:516-522. doi:10.1111/codi.2019.21.issue-5

38. Klaver CEL, Gietelink L, Bemelman WA, et al. Locally advanced colon cancer; current clinical practice and treatment outcome in the Netherlands. Color Dis. 2015;17:23. 


\section{Supplementary materials}

\begin{tabular}{|c|}
\hline UZ Leuven \\
Jan 2004-Jul 2013 \\
Inclusion: colorectal cancer \\
$\mathrm{N}=483$ \\
\hline
\end{tabular}

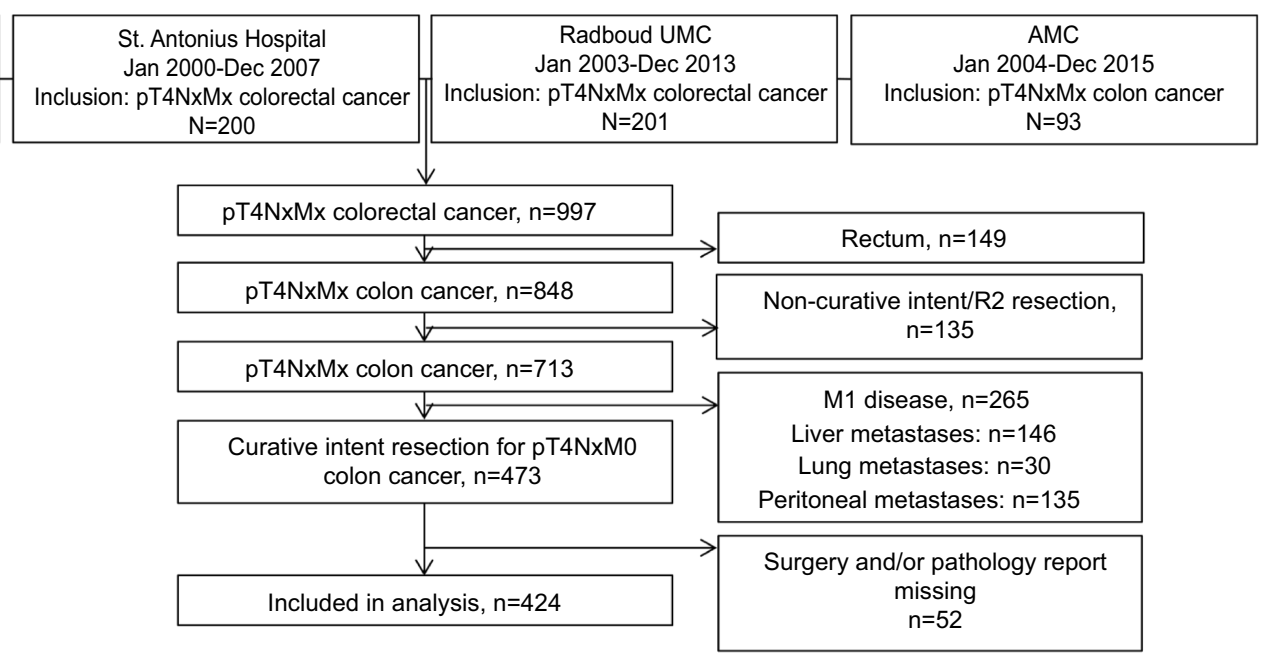

Figure SI Patients included in the analysis.

Abbreviations: $\mathrm{pT} / \mathrm{N}$, pathological T/N-stage; R2, macroscopically irradical resection; MI, metastatic disease; UZ, University hospital Leuven; Radboud UMC, Radboud University Medical Centre; AMC, Amsterdam University Medical Centre, location academic medical centre; Jan, January; Jul, July; Dec, December. 


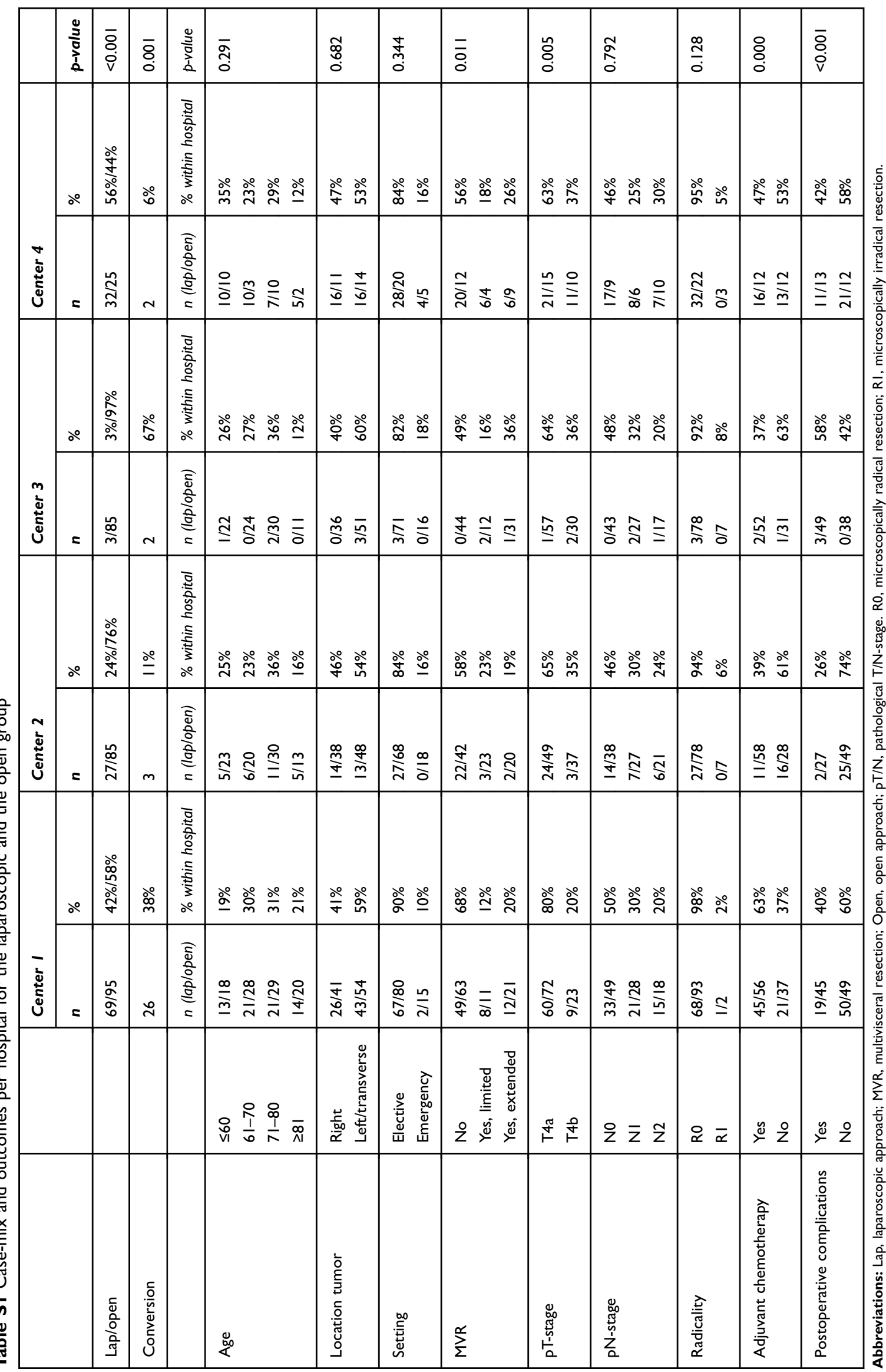


Table S2 Short-term outcomes after laparoscopic and open surgery; postoperative morbidity

\begin{tabular}{|c|c|c|c|c|c|c|c|c|c|c|}
\hline & \multirow[t]{2}{*}{$\begin{array}{l}\text { Lap/ } \\
\text { Open }\end{array}$} & \multicolumn{3}{|c|}{$\begin{array}{l}\text { Postop Complications } \\
\text { (CD2) }\end{array}$} & \multicolumn{3}{|c|}{$\begin{array}{l}\text { Postop Complications } \\
\text { (CD3/4) }\end{array}$} & \multicolumn{3}{|c|}{ Postop Mortality (CD5) } \\
\hline & & Lap & Open & p-value & Lap & Open & p-value & Lap & Open & p-value \\
\hline Unadjusted & $13 \mid / 293$ & $19(15 \%)$ & $66(23 \%)$ & 0.057 & $14(1 \mid \%)$ & $61(21 \%)$ & 0.012 & $2(2 \%)$ & $8(3 \%)$ & 0.357 \\
\hline \multicolumn{11}{|c|}{$\begin{array}{l}\text { Propensity score adjusted } \\
\text { models }\end{array}$} \\
\hline Matched cohort & $|3| /|3|$ & $19(15 \%)$ & $4 I(31 \%)$ & 0.001 & I4 (I I\%) & 45 (34\%) & 0.001 & $2(2 \%)$ & $8(6 \%)$ & 0.051 \\
\hline Stratum I & $15 / 90$ & $5(33 \%)$ & $20(22 \%)$ & 0.350 & I (7\%) & $23(26 \%)$ & 0.182 & $0(0 \%)$ & $5(5.6 \%)$ & 0.455 \\
\hline Stratum 2 & $32 / 75$ & $6(19 \%)$ & $15(20 \%)$ & 0.882 & $2(6 \%)$ & $19(25 \%)$ & 0.032 & I (3\%) & I (I\%) & 0.511 \\
\hline Stratum 3 & $39 / 69$ & $5(13 \%)$ & $14(20 \%)$ & 0.327 & $5(13 \%)$ & $12(17 \%)$ & 0.531 & $0(0 \%)$ & I (I\%) & 0.639 \\
\hline Stratum 4 & $45 / 59$ & $3(7 \%)$ & 17 (29\%) & 0.005 & $6(13 \%)$ & 7 (I2\%) & 0.822 & I (2\%) & I (2\%) & $0.68 I$ \\
\hline \multicolumn{11}{|l|}{ Sensitivity analyses } \\
\hline No MVR & $91 / 162$ & $9(10 \%)$ & $37(23 \%)$ & 0.010 & II (I2\%) & $28(17 \%)$ & 0.272 & I (I\%) & $3(2 \%)$ & 0.546 \\
\hline Limited MVR & $19 / 50$ & $4(21 \%)$ & $10(20 \%)$ & 1.000 & I (5\%) & $8(16 \%)$ & 0.237 & I (5\%) & $2(4 \%)$ & 0.626 \\
\hline Extended MVR & $21 / 81$ & $6(29 \%)$ & $19(24 \%)$ & 0.627 & $2(10 \%)$ & $25(31 \%)$ & 0.048 & $0(0 \%)$ & $3(4 \%)$ & 0.371 \\
\hline Elective & $125 / 239$ & 17 (14\%) & 55 (23\%) & 0.032 & $13(10 \%)$ & 46 (19\%) & 0.030 & $2(2 \%)$ & $5(2 \%)$ & 0.745 \\
\hline Emergency & $6 / 54$ & 2 (33\%) & II (20\%) & 0.602 & I (I7\%) & 15 (28\%) & 0.559 & $0(0 \%)$ & $3(6 \%)$ & 0.725 \\
\hline
\end{tabular}

Abbreviations: CD, Clavien-Dindo score; Lap, laparoscopic approach; MVR, multivisceral resection; Open, open approach; Unadjusted, the unadjusted (entire) cohort. 
Table S3 Baseline characteristics of stratum I (lowest propensity for laparoscopic surgery) for the laparoscopic and the open group

\begin{tabular}{|c|c|c|c|c|c|c|}
\hline & & \multicolumn{2}{|c|}{ Laparoscopic $(n=\mid 5)$} & \multicolumn{2}{|c|}{ Open $(n=90)$} & \multirow[t]{2}{*}{$p$-value } \\
\hline & & $n$ & $\%$ & $n$ & $\%$ & \\
\hline Gender & $\begin{array}{l}\text { Male } \\
\text { Female }\end{array}$ & $\begin{array}{l}7 \\
8\end{array}$ & $\begin{array}{l}47 \% \\
53 \%\end{array}$ & $\begin{array}{l}53 \\
37\end{array}$ & $\begin{array}{l}59 \% \\
41 \%\end{array}$ & 0.376 \\
\hline Age & $\begin{array}{l}\leq 60 \\
61-70 \\
71-80 \\
\geq 81\end{array}$ & $\begin{array}{l}3 \\
3 \\
8 \\
1\end{array}$ & $\begin{array}{l}20 \% \\
20 \% \\
53 \% \\
7 \%\end{array}$ & $\begin{array}{l}27 \\
15 \\
35 \\
13\end{array}$ & $\begin{array}{l}30 \% \\
17 \% \\
39 \% \\
14 \%\end{array}$ & 0.621 \\
\hline Hospital & $\begin{array}{l}\text { Center } 1 \\
\text { Center } 2 \\
\text { Center } 3 \\
\text { Center } 4\end{array}$ & $\begin{array}{l}5 \\
2 \\
1 \\
7\end{array}$ & $\begin{array}{l}33 \% \\
13 \% \\
7 \% \\
47 \%\end{array}$ & $\begin{array}{l}24 \\
26 \\
31 \\
9\end{array}$ & $\begin{array}{l}27 \% \\
29 \% \\
34 \% \\
10 \%\end{array}$ & 0.001 \\
\hline Location tumour & $\begin{array}{l}\text { Right } \\
\text { Left/transverse }\end{array}$ & $\begin{array}{l}10 \\
5\end{array}$ & $\begin{array}{l}67 \% \\
33 \%\end{array}$ & $\begin{array}{l}36 \\
54\end{array}$ & $\begin{array}{l}40 \% \\
60 \%\end{array}$ & 0.054 \\
\hline Surgical procedure & $\begin{array}{l}\text { (Extended) right hemicolectomy } \\
\text { Transverse resection } \\
\text { (Extended) left hemicolectomy } \\
\text { (Low) anterior/sigmoid resection } \\
\text { Subtotal/panprocto-colectomy }\end{array}$ & $\begin{array}{l}8 \\
0 \\
1 \\
5 \\
1\end{array}$ & $\begin{array}{l}53 \% \\
0 \% \\
7 \% \\
33 \% \\
7 \%\end{array}$ & $\begin{array}{l}36 \\
3 \\
12 \\
31 \\
8\end{array}$ & \begin{tabular}{l|}
$40 \%$ \\
$3 \%$ \\
$13 \%$ \\
$34 \%$ \\
$9 \%$
\end{tabular} & 0.811 \\
\hline Setting & $\begin{array}{l}\text { Elective } \\
\text { Emergency }\end{array}$ & $\begin{array}{l}9 \\
6\end{array}$ & $\begin{array}{l}60 \% \\
40 \%\end{array}$ & $\begin{array}{l}36 \\
54\end{array}$ & $\begin{array}{l}40 \% \\
60 \%\end{array}$ & 0.147 \\
\hline Neoadjuvant therapy & $\begin{array}{l}\text { Yes } \\
\text { No }\end{array}$ & $\begin{array}{l}0 \\
13\end{array}$ & $\begin{array}{l}0 \% \\
100 \%\end{array}$ & $\begin{array}{l}2 \\
88\end{array}$ & $\begin{array}{l}2 \% \\
98 \%\end{array}$ & 0.762 \\
\hline MVR & $\begin{array}{l}\text { No } \\
\text { Yes, limited } \\
\text { Yes, extended }\end{array}$ & $\begin{array}{l}4 \\
3 \\
8\end{array}$ & $\begin{array}{l}27 \% \\
20 \% \\
53 \%\end{array}$ & $\begin{array}{l}29 \\
17 \\
44\end{array}$ & $\begin{array}{l}32 \% \\
19 \% \\
49 \%\end{array}$ & 0.911 \\
\hline Conversion & & 4 & $27 \%$ & & & \\
\hline T-stage & $\begin{array}{l}\mathrm{T} 4 \mathrm{a} \\
\mathrm{T} 4 \mathrm{~b}\end{array}$ & $\begin{array}{l}8 \\
7\end{array}$ & $\begin{array}{l}53 \% \\
47 \%\end{array}$ & $\begin{array}{l}45 \\
45\end{array}$ & $\begin{array}{l}50 \% \\
50 \%\end{array}$ & 0.811 \\
\hline $\mathrm{N}$-stage & $\begin{array}{l}\text { No } \\
\text { NI } \\
\text { N2 }\end{array}$ & $\begin{array}{l}9 \\
4 \\
2\end{array}$ & $\begin{array}{l}60 \% \\
27 \% \\
13 \%\end{array}$ & $\begin{array}{l}40 \\
30 \\
20\end{array}$ & $\begin{array}{l}44 \% \\
33 \% \\
22 \%\end{array}$ & 0.515 \\
\hline Histology & $\begin{array}{l}\text { Adenocarcinoma (well diff) } \\
\text { Adenocarcinoma (poorly/undiff) } \\
\text { Mucinous/signet ring cells }\end{array}$ & $\begin{array}{l}8 \\
6 \\
1\end{array}$ & $\begin{array}{l}53 \% \\
40 \% \\
7 \%\end{array}$ & $\begin{array}{l}49 \\
27 \\
14\end{array}$ & $\begin{array}{l}54 \% \\
30 \% \\
16 \%\end{array}$ & 0.570 \\
\hline
\end{tabular}

Abbreviations: Lap, laparoscopic approach; MVR, multivisceral resection; NA, not applicable; Open, open approach; pT/N, pathological T/N-stage; Undiff, undifferentiated; Well diff, well differentiated. 
Table S4 Baseline characteristics of stratum 2 for the laparoscopic and the open group

\begin{tabular}{|c|c|c|c|c|c|c|}
\hline & & \multicolumn{2}{|c|}{ Laparoscopic $(n=32)$} & \multicolumn{2}{|c|}{ Open $(n=75)$} & \multirow[t]{2}{*}{$p$-value } \\
\hline & & $n$ & $\%$ & $n$ & $\%$ & \\
\hline \multirow[t]{2}{*}{ Gender } & Male & 16 & $50 \%$ & 33 & $44 \%$ & \multirow[t]{2}{*}{0.568} \\
\hline & Female & 16 & $50 \%$ & 42 & $56 \%$ & \\
\hline \multirow[t]{4}{*}{ Age } & $\leq 60$ & 8 & $25 \%$ & 20 & $27 \%$ & \multirow[t]{4}{*}{0.416} \\
\hline & $61-70$ & 14 & $44 \%$ & 21 & $28 \%$ & \\
\hline & $7 \mid-80$ & 7 & $22 \%$ & 25 & $33 \%$ & \\
\hline & $\geq 81$ & 3 & $9 \%$ & 9 & $12 \%$ & \\
\hline \multirow[t]{4}{*}{ Hospital } & Center I & 19 & $59 \%$ & 20 & $27 \%$ & \multirow[t]{4}{*}{0.001} \\
\hline & Center 2 & 5 & $16 \%$ & 25 & $33 \%$ & \\
\hline & Center 3 & 2 & $6 \%$ & 22 & $29 \%$ & \\
\hline & Center 4 & 6 & $19 \%$ & 8 & $11 \%$ & \\
\hline \multirow[t]{2}{*}{ Location tumour } & Right & 15 & $47 \%$ & 30 & $40 \%$ & \multirow[t]{2}{*}{0.510} \\
\hline & Left/transverse & 17 & $53 \%$ & 45 & $60 \%$ & \\
\hline \multirow[t]{5}{*}{ Surgical procedure } & (Extended) right hemicolectomy & 14 & $44 \%$ & 32 & $43 \%$ & \multirow[t]{5}{*}{0.673} \\
\hline & Transverse resection & 0 & $0 \%$ & 2 & $3 \%$ & \\
\hline & (Extended) left hemicolectomy & 4 & $13 \%$ & 6 & $8 \%$ & \\
\hline & (Low) anterior/sigmoid resection & 12 & $37 \%$ & 33 & $44 \%$ & \\
\hline & Subtotal/panprocto-colectomy & 2 & $6 \%$ & 2 & $3 \%$ & \\
\hline \multirow[t]{2}{*}{ Setting } & Elective & 32 & $100 \%$ & 75 & $100 \%$ & \\
\hline & Emergency & 0 & $0 \%$ & 0 & $0 \%$ & \\
\hline \multirow[t]{2}{*}{ Neoadjuvant therapy } & Yes & 30 & $94 \%$ & 65 & $87 \%$ & \multirow[t]{2}{*}{0.240} \\
\hline & No & 2 & $6 \%$ & 10 & $13 \%$ & \\
\hline \multirow[t]{3}{*}{ MVR } & No & 7 & $22 \%$ & 18 & $24 \%$ & \multirow[t]{3}{*}{0.525} \\
\hline & Yes, limited & 12 & $38 \%$ & 20 & $27 \%$ & \\
\hline & Yes, extended & 13 & $41 \%$ & 37 & $49 \%$ & \\
\hline Conversion & & 16 & $50 \%$ & & & \\
\hline \multirow[t]{2}{*}{ T-stage } & T4a & 17 & $53 \%$ & 30 & $40 \%$ & \multirow[t]{2}{*}{0.210} \\
\hline & T4b & 15 & $47 \%$ & 45 & $60 \%$ & \\
\hline \multirow[t]{3}{*}{ N-stage } & No & 15 & $47 \%$ & 39 & $52 \%$ & \multirow[t]{3}{*}{0.874} \\
\hline & $\mathrm{NI}$ & 9 & $28 \%$ & 20 & $27 \%$ & \\
\hline & N2 & 8 & $25 \%$ & 16 & $21 \%$ & \\
\hline \multirow[t]{3}{*}{ Histology } & Adenocarcinoma (well diff) & 21 & $66 \%$ & 47 & $63 \%$ & \multirow[t]{3}{*}{0.955} \\
\hline & Adenocarcinoma (poorly/undiff) & 8 & $25 \%$ & 20 & $27 \%$ & \\
\hline & Mucinous/signet ring cells & 3 & $9 \%$ & 8 & $11 \%$ & \\
\hline
\end{tabular}

Abbreviations: Lap, laparoscopic approach; MVR, multivisceral resection; NA, not applicable; Open, open approach, pT/N: pathological T/N-stage, Undiff: undifferentiated; Well diff, well differentiated. 
Table S5 Baseline characteristics of stratum 3 for the laparoscopic and the open group

\begin{tabular}{|c|c|c|c|c|c|c|}
\hline & & \multicolumn{2}{|c|}{ Laparoscopic $(n=39)$} & \multicolumn{2}{|c|}{ Open $(n=69)$} & \multirow[t]{2}{*}{$p$-value } \\
\hline & & $n$ & $\%$ & $n$ & $\%$ & \\
\hline Gender & $\begin{array}{l}\text { Male } \\
\text { Female }\end{array}$ & $\begin{array}{l}21 \\
18\end{array}$ & $\begin{array}{l}54 \% \\
46 \%\end{array}$ & $\begin{array}{l}38 \\
31\end{array}$ & $\begin{array}{l}55 \% \\
45 \%\end{array}$ & 0.902 \\
\hline Age & $\begin{array}{l}\leq 60 \\
61-70 \\
71-80 \\
\geq 81\end{array}$ & $\begin{array}{l}15 \\
2 \\
15 \\
7\end{array}$ & $\begin{array}{l}38 \% \\
5 \% \\
39 \% \\
18 \%\end{array}$ & $\begin{array}{l}21 \\
12 \\
30 \\
6\end{array}$ & $\begin{array}{l}30 \% \\
17 \% \\
44 \% \\
9 \%\end{array}$ & 0.151 \\
\hline Hospital & $\begin{array}{l}\text { Center } 1 \\
\text { Center } 2 \\
\text { Center } 3 \\
\text { Center } 4\end{array}$ & $\begin{array}{l}23 \\
8 \\
0 \\
8\end{array}$ & $\begin{array}{l}59 \% \\
21 \% \\
0 \% \\
21 \%\end{array}$ & $\begin{array}{l}23 \\
21 \\
19 \\
6\end{array}$ & $\begin{array}{l}33 \% \\
30 \% \\
28 \% \\
9 \%\end{array}$ & $<0.001$ \\
\hline Location tumour & $\begin{array}{l}\text { Right } \\
\text { Left/transverse }\end{array}$ & $\begin{array}{l}22 \\
17\end{array}$ & $\begin{array}{l}56 \% \\
44 \%\end{array}$ & $\begin{array}{l}41 \\
28\end{array}$ & $\begin{array}{l}59 \% \\
41 \%\end{array}$ & $0.76 \mathrm{I}$ \\
\hline Surgical procedure & $\begin{array}{l}\text { (Extended) right hemicolectomy } \\
\text { Transverse resection } \\
\text { (Extended) left hemicolectomy } \\
\text { (Low) anterior/sigmoid resection } \\
\text { Subtotal/panprocto-colectomy }\end{array}$ & $\begin{array}{l}22 \\
0 \\
2 \\
13 \\
2\end{array}$ & $\begin{array}{l}56 \% \\
0 \% \\
5 \% \\
33 \% \\
5 \%\end{array}$ & $\begin{array}{l}39 \\
2 \\
11 \\
12 \\
5\end{array}$ & $\begin{array}{l}57 \% \\
3 \% \\
16 \% \\
17 \% \\
7 \%\end{array}$ & 0.167 \\
\hline Setting & $\begin{array}{l}\text { Elective } \\
\text { Emergency }\end{array}$ & $\begin{array}{l}39 \\
0\end{array}$ & $\begin{array}{l}100 \% \\
0 \%\end{array}$ & $\begin{array}{l}69 \\
0\end{array}$ & $\begin{array}{l}100 \% \\
0 \%\end{array}$ & \\
\hline Neoadjuvant therapy & $\begin{array}{l}\text { Yes } \\
\text { No }\end{array}$ & $\begin{array}{l}3 \\
36\end{array}$ & $\begin{array}{l}8 \% \\
92 \%\end{array}$ & $\begin{array}{l}0 \\
69\end{array}$ & $\begin{array}{l}0 \% \\
100 \%\end{array}$ & 0.045 \\
\hline MVR & $\begin{array}{l}\text { No } \\
\text { Yes, limited } \\
\text { Yes, extended }\end{array}$ & $\begin{array}{l}35 \\
4 \\
0\end{array}$ & $\begin{array}{l}90 \% \\
10 \% \\
0 \%\end{array}$ & $\begin{array}{l}56 \\
16 \\
0\end{array}$ & $\begin{array}{l}81 \% \\
19 \% \\
0 \%\end{array}$ & 0.239 \\
\hline Conversion & & 8 & $21 \%$ & & & \\
\hline T-stage & $\begin{array}{l}\mathrm{T} 4 \mathrm{a} \\
\mathrm{T} 4 \mathrm{~b}\end{array}$ & $\begin{array}{l}36 \\
3\end{array}$ & $\begin{array}{l}92 \% \\
8 \%\end{array}$ & $\begin{array}{l}59 \\
10\end{array}$ & $\begin{array}{l}86 \% \\
14 \%\end{array}$ & 0.369 \\
\hline $\mathrm{N}$-stage & $\begin{array}{l}\text { No } \\
\text { NI } \\
\text { N2 }\end{array}$ & $\begin{array}{l}9 \\
16 \\
14\end{array}$ & $\begin{array}{l}23 \% \\
41 \% \\
36 \%\end{array}$ & $\begin{array}{l}19 \\
27 \\
23\end{array}$ & $\begin{array}{l}28 \% \\
39 \% \\
33 \%\end{array}$ & 0.877 \\
\hline Histology & $\begin{array}{l}\text { Adenocarcinoma (well diff) } \\
\text { Adenocarcinoma (poorly/undiff) } \\
\text { Mucinous/signet ring cells }\end{array}$ & $\begin{array}{l}28 \\
1 \\
10\end{array}$ & $\begin{array}{l}71 \% \\
3 \% \\
26 \%\end{array}$ & $\begin{array}{l}47 \\
3 \\
19\end{array}$ & $\begin{array}{l}69 \% \\
4 \% \\
28 \%\end{array}$ & 0.862 \\
\hline
\end{tabular}

Abbreviations: Lap, laparoscopic approach; MVR, multivisceral resection; NA, not applicable; Open, open approach; pT/N, pathological T/N-stage; Undiff, undifferentiated; Well diff, well differentiated. 
Table S6 Baseline characteristics of stratum 4 (highest propensity for laparoscopic surgery) for the laparoscopic and the open group

\begin{tabular}{|c|c|c|c|c|c|c|}
\hline & & \multicolumn{2}{|c|}{ Laparoscopic $(n=45)$} & \multicolumn{2}{|c|}{ Open $(n=59)$} & \multirow[t]{2}{*}{$p$-value } \\
\hline & & $n$ & $\%$ & $n$ & $\%$ & \\
\hline \multirow[t]{2}{*}{ Gender } & Male & 24 & $53 \%$ & 24 & $41 \%$ & \multirow[t]{2}{*}{0.200} \\
\hline & Female & 21 & $47 \%$ & 35 & $59 \%$ & \\
\hline \multirow[t]{4}{*}{ Age } & $\leq 60$ & 3 & $7 \%$ & 5 & $9 \%$ & \multirow[t]{4}{*}{0.694} \\
\hline & $61-70$ & 18 & $40 \%$ & 27 & $46 \%$ & \\
\hline & $71-80$ & II & $24 \%$ & 9 & $15 \%$ & \\
\hline & $\geq 81$ & 13 & $29 \%$ & 18 & $31 \%$ & \\
\hline \multirow[t]{4}{*}{ Hospital } & Center I & 22 & $49 \%$ & 28 & $48 \%$ & \multirow[t]{4}{*}{$<0.001$} \\
\hline & Center 2 & 12 & $27 \%$ & 14 & $24 \%$ & \\
\hline & Center 3 & 0 & $0 \%$ & 15 & $25 \%$ & \\
\hline & Center 4 & 11 & $24 \%$ & 2 & $3 \%$ & \\
\hline \multirow[t]{2}{*}{ Location tumour } & Right & 9 & $20 \%$ & 19 & $32 \%$ & \multirow[t]{2}{*}{0.165} \\
\hline & Left/transverse & 36 & $80 \%$ & 40 & $68 \%$ & \\
\hline \multirow[t]{5}{*}{ Surgical procedure } & (Extended) right hemicolectomy & 16 & $36 \%$ & 20 & $34 \%$ & \multirow[t]{5}{*}{0.263} \\
\hline & Transverse resection & 0 & $0 \%$ & 1 & $2 \%$ & \\
\hline & (Extended) left hemicolectomy & 6 & $13 \%$ & 13 & $22 \%$ & \\
\hline & (Low) anterior/sigmoid resection & 21 & $47 \%$ & 18 & $31 \%$ & \\
\hline & Subtotal/panprocto-colectomy & 2 & $4 \%$ & 7 & $12 \%$ & \\
\hline \multirow[t]{2}{*}{ Setting } & Elective & 45 & $100 \%$ & 59 & $100 \%$ & \\
\hline & Emergency & 0 & $0 \%$ & 0 & $0 \%$ & \\
\hline \multirow[t]{2}{*}{ Neoadjuvant therapy } & Yes & 0 & $0 \%$ & 2 & $3 \%$ & \multirow[t]{2}{*}{0.212} \\
\hline & No & 45 & $100 \%$ & 57 & $97 \%$ & \\
\hline \multirow[t]{3}{*}{ MVR } & No & 45 & $100 \%$ & 59 & $100 \%$ & \\
\hline & Yes, limited & 0 & $0 \%$ & 0 & $0 \%$ & \\
\hline & Yes, extended & 0 & $0 \%$ & 0 & $0 \%$ & \\
\hline Conversion & & 5 & $14 \%$ & & & \\
\hline \multirow[t]{2}{*}{ T-stage } & T4a & 45 & $100 \%$ & 59 & $100 \%$ & \\
\hline & T4b & 0 & $0 \%$ & 0 & $0 \%$ & \\
\hline \multirow[t]{3}{*}{ N-stage } & No & 31 & $69 \%$ & 41 & $70 \%$ & \multirow[t]{3}{*}{$0.98 \mathrm{I}$} \\
\hline & $\mathrm{NI}$ & 9 & $20 \%$ & II & $19 \%$ & \\
\hline & N2 & 5 & $11 \%$ & 7 & $12 \%$ & \\
\hline \multirow[t]{3}{*}{ Histology } & Adenocarcinoma (well diff) & 37 & $82 \%$ & 54 & $91 \%$ & \multirow[t]{3}{*}{0.155} \\
\hline & Adenocarcinoma (poorly/undiff) & 0 & 0 & 0 & $0 \%$ & \\
\hline & Mucinous/signet ring cells & 8 & $18 \%$ & 5 & 9 & \\
\hline
\end{tabular}

Abbreviations: Lap, laparoscopic approach; MVR, multivisceral resection; NA, not applicable; Open, open approach; pT/N, pathological T/N-stage; Undiff, undifferentiated; Well diff: well differentiated.

Cancer Management and Research

Dovepress

\section{Publish your work in this journal}

Cancer Management and Research is an international, peer-reviewed open access journal focusing on cancer research and the optimal use of preventative and integrated treatment interventions to achieve improved outcomes, enhanced survival and quality of life for the cancer patient.

The manuscript management system is completely online and includes a very quick and fair peer-review system, which is all easy to use. Visit http://www.dovepress.com/testimonials.php to read real quotes from published authors. 